\title{
Synergistic Effects of a Night Temperature Shift and Methyl Jasmonate on the Production of Anthocyanin in Red Leaf Lettuce
}

\author{
Masaru Sakamoto*, Takahiro Suzuki \\ Faculty of Biology-Oriented Science and Technology, Kindai University, Wakayama, Japan \\ Email: *sakamoto@waka.kindai.ac.jp
}

How to cite this paper: Sakamoto, M. and Suzuki, T. (2017) Synergistic Effects of a Night Temperature Shift and Methyl Jasmonate on the Production of Anthocyanin in Red Leaf Lettuce. American Journal of Plant Sciences, 8, 1534-1549.

https://doi.org/10.4236/ajps.2017.87106

Received: March 11, 2017

Accepted: June 13, 2017

Published: June 16, 2017

Copyright (c) 2017 by authors and Scientific Research Publishing Inc. This work is licensed under the Creative Commons Attribution International License (CC BY 4.0).

http://creativecommons.org/licenses/by/4.0/

\section{(c) (i) Open Access}

\begin{abstract}
The production of a secondary metabolite such as anthocyanin is coordinately regulated by plant intrinsic factors and influenced by multiple environmental factors. In red leaf lettuce, the red pigment component anthocyanin is important for the commercial value of the crop, but its synchronous regulation by multiple factors is not well understood. Here, we examined the synergistic effects of a night temperature shift and methyl jasmonate (MJ) on the production of anthocyanin in red leaf lettuce. Low or high night temperature treatment for 3 days just before harvesting induced the production of anthocyanin without affecting plant biomass. Temperature-dependent activation of anthocyanin accumulation was accelerated by treating with MJ. Night temperature shifts and MJ triggered oxidative stresses in leaves, as indicated by hydrogen peroxide accumulation and lipid peroxidation. Interestingly, these oxidative stresses were more evident in leaves simultaneously treated with both a high night temperature and MJ. The activity of the superoxide dismutase (SOD) was increased alongside the elevation of oxidative stress. Taken together, these results indicate that the combined treatment of a night temperature shift with MJ may accelerate anthocyanin production by increasing the levels of oxidative stress to the leaves of red leaf lettuce.
\end{abstract}

\section{Keywords}

Anthocyanin, Night Temperature, Methyl Jasmonate, Red Leaf Lettuce, Oxidative Stress

\section{Introduction}

Plants can activate secondary metabolic pathways in response to a variety of environmental stresses, such as light, temperature, salinity, drought, and pathogens 
[1] [2]. Indeed, a high or low temperature will often increase the production of secondary metabolites [3] [4] [5]. High temperature stress, for example, induced leaf senescence and increased the secondary metabolite concentrations in the root of the herb Panax quinquefolius [6]. Spinach plants grown at a low temperature increased their production of sugar and ascorbic acid in leaves compared with those grown under ambient conditions [7]. In strawberry plants, the amount of ascorbic acid in the fruits increased when these plants were exposed to low temperature [8], whereas anthocyanin decreased at a high temperature [9]. Thus, controlling the cultivation temperature may be an effective strategy for producing value-added crops that contain high amounts of useful secondary metabolites for humans.

Methyl jasmonate (MJ) is one of the organic volatile compounds involved in various developmental processes, such as those of seed germination, root elongation, flowering, fruit ripening, and aging [10] [11]. In addition, when a plant undergoes several stresses such as necrotrophic bacteria, insect attacks, and wounding, it releases MJ to initiate the local and systemic responses, which includes secondary metabolite production, to defend itself and neighboring plants [11]. Utilizing this property of MJ, the application of exogenous MJ treatment has been studied for enhancing the amount of secondary metabolites in various crop plants [12] [13] [14]. In sweet basil, the total phenolic content and two valuable phenolic compounds, rosmarinic acid and caffeic acid, are induced by an MJ treatment [12]. Anthocyanins, a phenolic compound better known as plant red pigments, have also been induced by $\mathrm{MJ}$ in Arabidopsis leaves, accompanied by the expression of a series of genes involved in the biosynthesis of anthocyanin [15].

In recent years, lettuces have been cultivated in plant factories, and there is more demand for technology to control these cultivation environments to increase the crop value to offset the high cultivation costs. Antioxidants, such as anthocyanins, are considered one of the functional ingredients that can increase the added value of crops [16]. To date, various environmental stresses have been shown that enhance the production of anthocyanin in plants [17]. In lettuces, it is reported that lowering the growth temperature during the night promotes the production of anthocyanin [18] [19] [20]. In these studies, the temperature shift is considered to impose only a mild stress to the plants since the growth temperature conditions are set within the range of $10^{\circ} \mathrm{C}$ to $30^{\circ} \mathrm{C}$. Lettuce anthocyanins are also induced by $\mathrm{MJ}$ treatment, as seen in other plants and for other metabolites [21] [22]. The MJ-induced anthocyanin accumulations are further enhanced by exposing plants to high light conditions in several plants [21] [23] [24]. Similarly, low temperature-induced anthocyanin production is dependent on the intensity of light in red leaf lettuce [20]. Although the light intensity is closely linked to the anthocyanin production triggered by temperature and MJ, the relationship between $\mathrm{MJ}$ and temperature in lettuce anthocyanin production is largely unknown. In the present study, we investigated the influence of high or low night temperature in combination with an $\mathrm{MJ}$ treatment on the anthocyanin 
production in red leaf lettuce. We also examined the oxidative stress parameters in these plants as exposed to different night temperatures and to $\mathrm{MJ}$ for a better understanding of the oxidative stress in the lettuce anthocyanin production.

\section{Materials and Methods}

\subsection{Plant Growth Conditions and the MJ Treatment}

Red leaf lettuce seeds (Lactuca sativa L. cv. Red Wave; Sakata Seed Co., Japan) were pre-germinated for 1 day at $20^{\circ} \mathrm{C}$ under $200 \mu \mathrm{mol} \cdot \mathrm{m}^{-2} \cdot \mathrm{s}^{-1}$ photosynthetic photon flux (PPF) for $12 \mathrm{~h}$ by using fluorescent lamps (FL40SBR-A; NEC Co., Japan). The germinated seeds were sown in sponge cubes of $2 \times 2 \times 2 \mathrm{~cm}$ where they were grown under the same prior conditions. The nutrient solution was based on a half-strength culture solution of the Otsuka House A-recipe (Otsuka Chemical Co., Japan). Plants were grown under a 12-h day/night cycle throughout the experiments. After 14 days from the date of sowing, the night temperature treatment was initiated by transferring plants to different temperature conditions at nighttime. The temperature of the day period was set at $20^{\circ} \mathrm{C}$ in all plants. MJ (5 mM) was sprayed onto the whole leaves for the last $1 \mathrm{~h}$ of night temperature treatment and all the plants were kept in the dark for $1 \mathrm{~h}$ at $20^{\circ} \mathrm{C}$. The control plants were sprayed with distilled water. These treatments were repeated for 3 days. After 17 days from the date of sowing, and just after exposure to light for $12 \mathrm{~h}$, the plants were harvested, and the growth and metabolite analyses were conducted. All experiments were repeated at least four times-all obtained similar results.

\subsection{Measurement of the Anthocyanin Content}

The anthocyanin content was spectrophotometrically measured as described elsewhere [25]. The second true leaves $(50 \mathrm{mg}$ ) were homogenized with $1 \mathrm{~mL}$ methanol containing $1 \%$ hydrochloric acid. After storage at $4^{\circ} \mathrm{C}$ overnight, each sample was centrifuged at $10,000 \mathrm{~g}$ for $5 \mathrm{~min}$ at room temperature. The absorbance of the supernatant was measured at $533 \mathrm{~nm}$, and a standard curve was prepared by using cyanidin-3-glucoside.

\subsection{Measurement of the Total Phenol Content}

The total phenol content was measured using the modified Folin-Ciocalteu method, as described previously [25]. The second true leaves $(50 \mathrm{mg})$ were homogenized with $500 \mu \mathrm{L}$ of $90 \%$ methanol. After storage at $4^{\circ} \mathrm{C}$ overnight, each sample was centrifuged at 10,000 $\mathrm{g}$ for $5 \mathrm{~min}$ at room temperature. The supernatant $(50 \mu \mathrm{L})$ was diluted with distilled water to $650 \mu \mathrm{L}$, and a $50 \mu \mathrm{L}$ of phenol reagent was mixed with it. After adding $300 \mu \mathrm{L}$ of $5 \%$ sodium carbonate the mixture was incubated at $25^{\circ} \mathrm{C}$ for $30 \mathrm{~min}$. The absorbance of the supernatant was measured at $765 \mathrm{~nm}$, and a standard curve was prepared by using gallic acid.

\subsection{Measurement of the Hydrogen Peroxide Content}

The hydrogen peroxide $\left(\mathrm{H}_{2} \mathrm{O}_{2}\right)$ content was spectrophotometrically measured as 
described previously [26] but with slight modifications. The second true leaves $(100 \mathrm{mg}$ ) were homogenized in $600 \mu \mathrm{L}$ of $1 \%$ trichloroacetic acid (TCA). Then each sample was centrifuged at $10,000 \mathrm{~g}$ for $10 \mathrm{~min}$. The supernatant $(250 \mu \mathrm{L})$ was added to $250 \mu \mathrm{L}$ of a $10 \mathrm{mM} \mathrm{K}$-phosphate buffer (pH 7.0) and $500 \mu \mathrm{L}$ of $1 \mathrm{M}$ KI. The absorbance of the mixture was measured at $390 \mathrm{~nm}$, and a standard curve was prepared by using $\mathrm{H}_{2} \mathrm{O}_{2}$ in the range from $25-500 \mu \mathrm{mol} \mathrm{mL} L^{-1}$.

\subsection{Measurement of the Thiobarbituric Acid Reaction Content}

The level of malondialdehyde-MDA, a lipid peroxidation product-was determined via the thiobarbituric acid reaction (TBAR) method [25] [27]. The second true leaves $(100 \mathrm{mg})$ were homogenized in $0.5 \mathrm{~mL}$ of a $0.1 \%$ TCA solution. After centrifuging at $10000 \mathrm{~g}$ for $5 \mathrm{~min}, 0.2 \mathrm{~mL}$ of the supernatant was added to 0.8 $\mathrm{mL}$ of $0.5 \%$ thiobarbituric acid in $20 \% \mathrm{TCA}$. The mixture was incubated at $95^{\circ} \mathrm{C}$ for $30 \mathrm{~min}$; the reaction was stopped by cooling on ice. After centrifuging at $10,000 \mathrm{~g}$ for $5 \mathrm{~min}$ at room temperature, the absorbance of the supernatant was measured at $532 \mathrm{~nm}$ and the nonspecific absorbance at $600 \mathrm{~nm}$ was subtracted. The concentration of MDA was quantified by using a molar extinction coefficient of $155 \mathrm{mM}^{-1} \cdot \mathrm{cm}^{-1}$.

\subsection{Measurement of Superoxide Dismutase Activity}

Superoxide dismutase (SOD) activity was spectrophotometrically measured as described previously [28], but with slight modifications. The second true leaves $(100 \mathrm{mg}$ ) were homogenized in $0.5 \mathrm{~mL}$ of a $50 \mathrm{mM}$ phosphate buffer $(\mathrm{pH} 7.0,0.1$ $\mathrm{mM}$ EDTA). The sample was centrifuged at $10,000 \mathrm{~g}$ for $10 \mathrm{~min}$. The supernatant $(2.5 \mu \mathrm{L})$ was added to $1 \mathrm{~mL}$ of a SOD reaction mixture $(50 \mathrm{mM}$ phosphate buffer [pH 7.7], $0.1 \mathrm{mM}$ EDTA, $13 \mathrm{mM}$ methionine, $75 \mu \mathrm{M}$ nitroblue tetrazolium [NBT], $2 \mu \mathrm{M}$ riboflavin). The reaction mixture was illuminated for $15 \mathrm{~min}$ at a light intensity of $300 \mu \mathrm{mol} \cdot \mathrm{m}^{-2} \cdot \mathrm{s}^{-1}$, and the absorbance was then monitored at $550 \mathrm{~nm}$. One unit of SOD activity was defined as the amount of enzyme required to inhibit the NBT reduction by $50 \%$. The total soluble proteins were determined spectrophotometrically by using the reagent Protein Assay Rapid Kit (Wako Ltd., Japan) and by applying the Bradford method in which bovine serum albumin was used as the standard.

\section{Results}

\subsection{Effects of Night Temperature on the Leaf Biomass in Red Leaf Lettuce}

Three-day treatments of five different night temperatures $\left(5^{\circ} \mathrm{C}, 10^{\circ} \mathrm{C}, 20^{\circ} \mathrm{C}\right.$, $30^{\circ} \mathrm{C}$, and $37^{\circ} \mathrm{C}$ ) did not significantly influence the leaf biomass of red leaf lettuce (Figure 1, Figure 2(A) and Figure 2(B)). By contrast, the water content of the leaves was significantly decreased by subjecting the lettuce plants to $5^{\circ} \mathrm{C}$ and $10^{\circ} \mathrm{C}$ low night temperatures as compared with the non-shifted control temperature $\left(20^{\circ} \mathrm{C}\right)$, while the high night temperature shifts did not significantly influence the leaf water content (Figure 2(C)). Water contents of plants grown at 


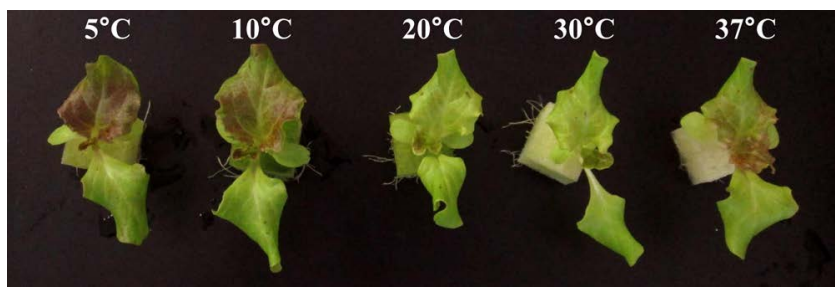

Figure 1. Effect of night temperature on the growth of red leaf lettuce plants.

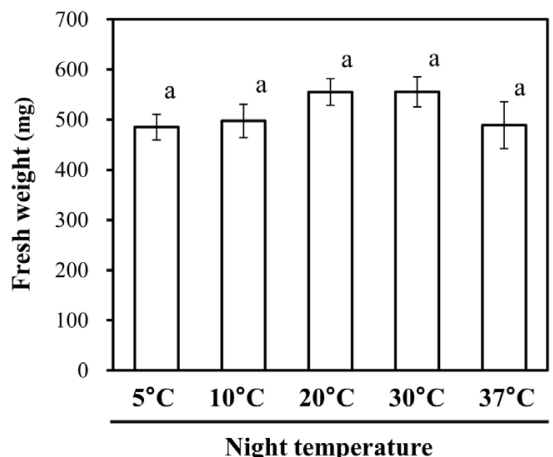

(A)

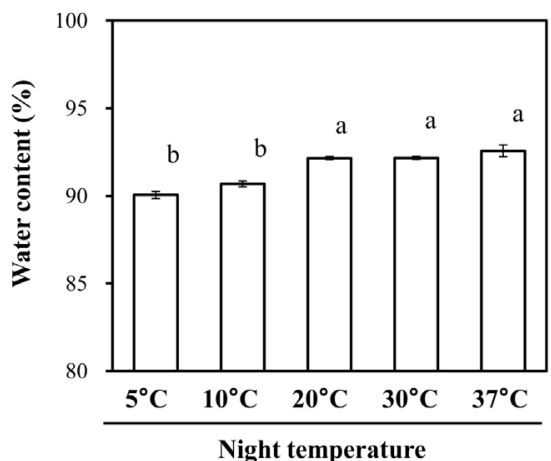

(C)

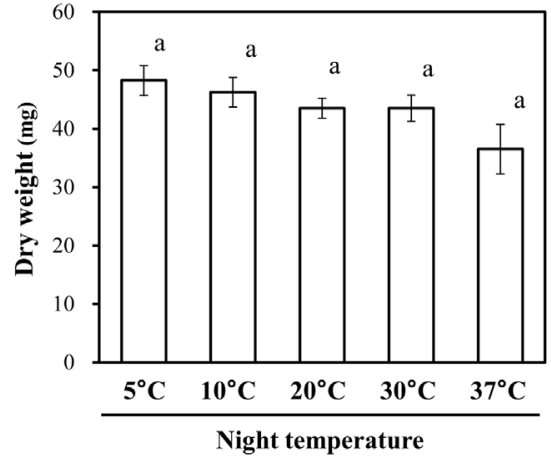

(B)

Figure 2. Effect of night temperature on the fresh weight (A); dry weight (B); and water content $(C)$ of red leaf lettuce leaves. Vertical bars represent the means \pm SEs $(n=4)$. Different letters indicate significant differences as determined by the Tukey's multiple comparison test $(p<0.05)$.

night temperature of $5^{\circ} \mathrm{C}, 20^{\circ} \mathrm{C}$, and $37^{\circ} \mathrm{C}$ were $90.1 \%, 92.2 \%$, and $92.6 \%$, respectively.

\subsection{Effect of Night Temperature on the Anthocyanin and Total Phenol Content in Red Leaf Lettuce}

Red pigmentation of the leaves was enhanced in those plants treated with low $\left(5^{\circ} \mathrm{C}\right.$ and $\left.10^{\circ} \mathrm{C}\right)$ or high $\left(37^{\circ} \mathrm{C}\right)$ night temperatures, especially in second true leaves (Figure 1). In agreement with this result, the production of anthocyanin in second true leaves was significantly increased by the treatment of low night temperatures as compared with the control plants grown at $20^{\circ} \mathrm{C}$ (Figure $3(\mathrm{~A})$ ). In plants grown at $5^{\circ} \mathrm{C}$ and $10^{\circ} \mathrm{C}$, their total leaf anthocyanin content increased about 4.0- and 2.8-fold, respectively, when compared with the control plants. The plants grown at a $37^{\circ} \mathrm{C}$ night temperature also displayed a 1.6 -fold increase 


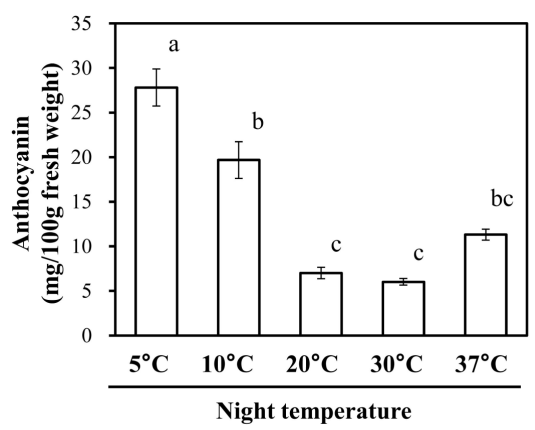

(A)

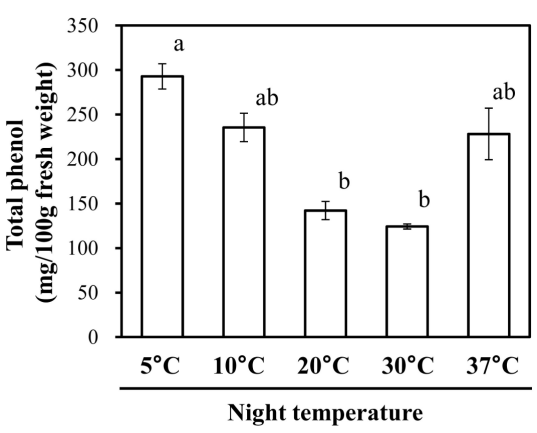

(B)

Figure 3. Effect of night temperature on the anthocyanin (A) and total phenol (B) contents of red leaf lettuce leaves. Vertical bars represent the means \pm SEs $(n=4)$. Different letters indicate significant differences as determined by the Tukey's multiple comparison test $(p<0.05)$.

in their amount of anthocyanin, though this difference was not significant (Figure 3(A)). Consistent with these results, the total phenol content of leaves exposed to either low or high temperatures at night was comparably increased as well (Figure $3(\mathrm{~B})$ ). The exposure of plants to temperatures of $5^{\circ} \mathrm{C}, 10^{\circ} \mathrm{C}$, and $37^{\circ} \mathrm{C}$ at night caused about 2.1-, 1.7-, and 1.6-fold increase in their total phenol content, respectively, as compared with the control plants. However, no apparent differences in the anthocyanin and total phenol contents were observed between $20^{\circ} \mathrm{C}$ (control) and the $30^{\circ} \mathrm{C}$ treated plants (Figure 3).

\subsection{Synergistic Effects of Night Temperature and MJ on the Leaf Biomass in Red Leaf Lettuce}

Next, we tested the combined effects of either a low $\left(5^{\circ} \mathrm{C}\right)$ or high $\left(37^{\circ} \mathrm{C}\right)$ night temperature with $\mathrm{MJ}$ on the leaf biomass and metabolites in red leaf lettuce. After the 3-day treatment, $\mathrm{MJ}$ tended to reduce the leaf biomass regardless of the night temperature (Figure 4(A) and Figure 4(B)). The MJ-induced biomass reduction was greater in plants exposed to the low night temperatures as compared with plants exposed to the high night temperature. Similarly, those plants exposed to MJ showed a tendency of decreased leaf water content irrespective of the night temperature treatment (Figure $4(C)$ ).

\subsection{Synergistic Effects of Night Temperature and MJ on the Anthocyanin and Total Phenol Contents in Red Leaf Lettuce}

The application of $\mathrm{MJ}$ increased the anthocyanin content in leaves regardless of the night temperature (Figure 5(A)). The effect of enhanced anthocyanin content by MJ was higher in those plants that were exposed to the high night temperature as compared with those that were co-treated with the low night temperature. The amounts of anthocyanin in leaves that were exposed to $5^{\circ} \mathrm{C}, 20^{\circ} \mathrm{C}$, and $37^{\circ} \mathrm{C}$ night temperatures and co-treated with $\mathrm{MJ}$ respectively were approximately 1.8-, 2.9-, and 2.7-fold higher than that in corresponding leaves untreated with MJ. Consistent with these results, the production of total phenol was up regulated by the MJ treatment at all tested temperatures (Figure 5(B)). 


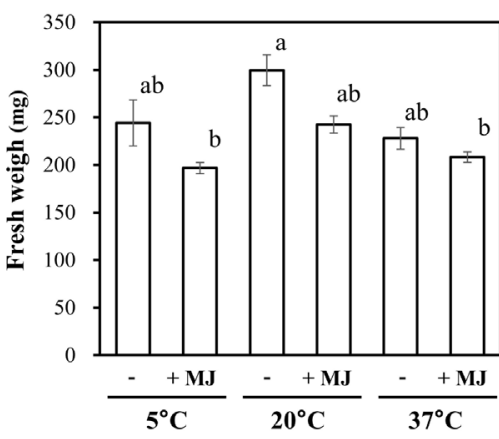

(A)

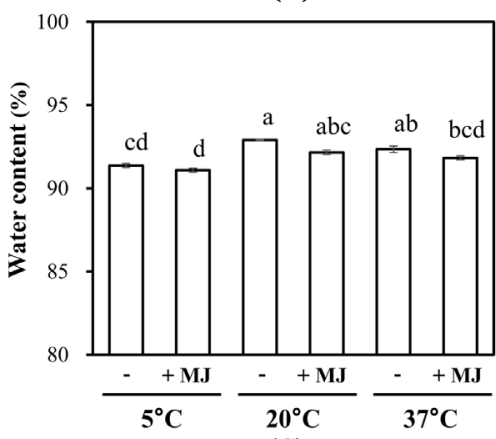

(C)

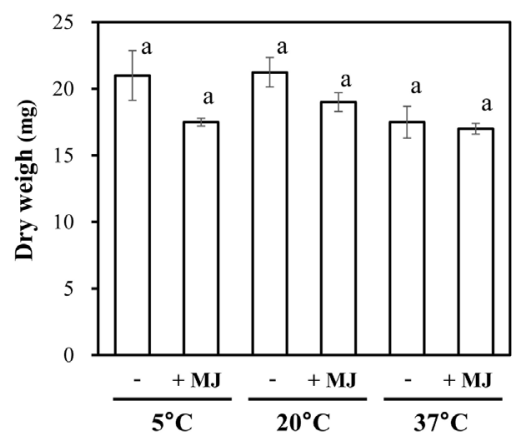

(B)

Figure 4. Effects of night temperature and $\mathrm{MJ}$ on the fresh weight (A), dry weight (B), and water content $(C)$ of red leaf lettuce leaves. Vertical bars represent the means \pm SEs $(n=4)$. Different letters indicate significant differences as determined by the Tukey's multiple comparison test $(p<0.05)$.

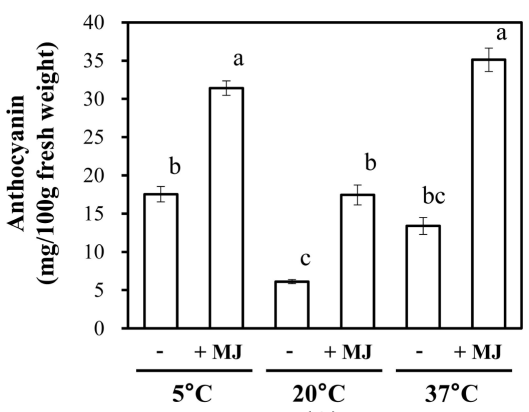

(A)

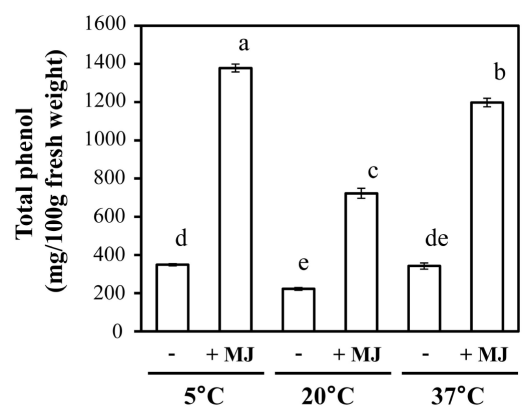

(B)

Figure 5. Effects of night temperature and MJ on the anthocyanin (A) and total phenol (B) contents of red leaf lettuce leaves. Vertical bars represent the means \pm SEs $(n=4)$. Different letters indicate significant differences as determined by the Tukey's multiple comparison test $(p<0.05)$.

The total phenol contents of leaves that were exposed to $5^{\circ} \mathrm{C}, 20^{\circ} \mathrm{C}$, and $37^{\circ} \mathrm{C}$ night temperatures and co-treated with $\mathrm{MJ}$ respectively were about 4.0-, 3.3-, and 3.5-fold higher than that in corresponding leaves untreated with MJ.

\subsection{Synergistic Effects of Night Temperature and MJ on the Oxidative Properties in Red Leaf Lettuce}

Anthocyanin accumulation is triggered by several oxidative stresses in plants [29] [30]. Therefore, we investigated the leaf $\mathrm{H}_{2} \mathrm{O}_{2}$ content in the experimental plants treated with night temperatures in combination with MJ. Low or high 
night temperatures triggered the production of $\mathrm{H}_{2} \mathrm{O}_{2}$ in the absence of $\mathrm{MJ}$ (Figure 6(A)). The MJ treatment up regulated the production of $\mathrm{H}_{2} \mathrm{O}_{2}$ at any of the night temperatures tested. The level of $\mathrm{H}_{2} \mathrm{O}_{2}$ was significantly higher in those plants exposed to a high night temperature in combination with $\mathrm{MJ}$ as compared with those exposed to a low night temperature in combination with MJ. The amounts of $\mathrm{H}_{2} \mathrm{O}_{2}$ in leaves that were exposed to $5^{\circ} \mathrm{C}, 20^{\circ} \mathrm{C}$, and $37^{\circ} \mathrm{C}$ night temperature and co-treated with $\mathrm{MJ}$ respectively were about 1.4-, 1.5-, and 2.0-fold higher than that in corresponding leaves untreated with MJ.

To monitor the marker for oxidative stress status we measured a lipid peroxidation products, MDA using the TBAR method. Consistent with the above changes found in the amount of leaf $\mathrm{H}_{2} \mathrm{O}_{2}$, MDA was induced by either low or high night temperatures, and it was accelerated by the $\mathrm{MJ}$ treatment (Figure 6(B)). The amount of MDA in leaves that were exposed to $5^{\circ} \mathrm{C}, 20^{\circ} \mathrm{C}$, and $37^{\circ} \mathrm{C}$ night temperatures and co-treated with $\mathrm{MJ}$ respectively were approximately1.3-, 1.2-, and 2.0-fold greater than that in corresponding leaves without MJ.

\subsection{Synergistic Effects of Night Temperature and MJ on the Activity of SOD in Red Leaf Lettuce}

Plants are able to mitigate oxidative stresses by activating antioxidative enzymes, such as SOD [31]. Hence, we also monitored the SOD activity of leaves in plants that were exposed to different night temperatures in combination with MJ. The SOD activity tended to increase at either a low or high night temperature treatment in the absence of MJ (Figure 7). Co-treatment with MJ up regulated the SOD activity, irrespective of any night temperature.

\section{Discussion}

\subsection{Effect of Low Night Temperature on the Production of Anthocyanin}

Low temperature induces the production of plant secondary metabolites, including anthocyanin, in various plants [17]. Similar to this view, our present re-

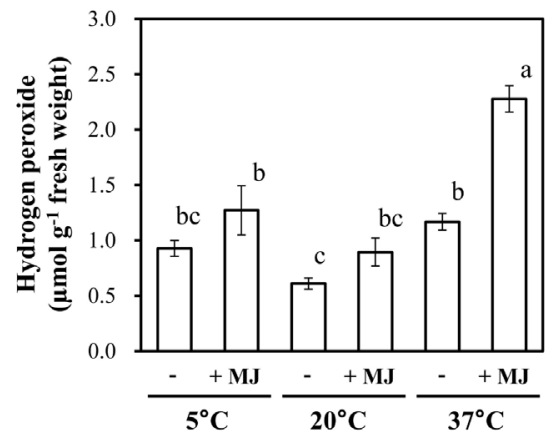

(A)

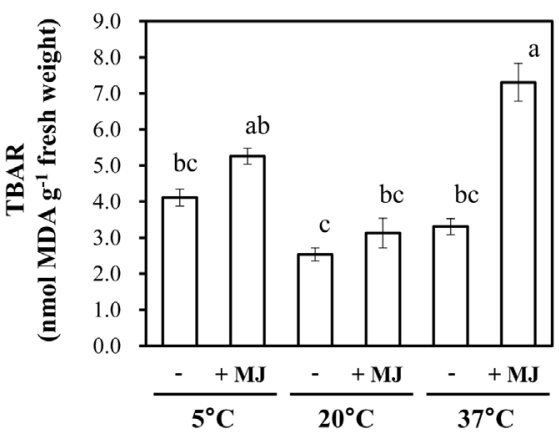

(B)

Figure 6. Effects of night temperature and $\mathrm{MJ}$ on the $\mathrm{H}_{2} \mathrm{O}_{2}$ content (A) and lipid peroxidation (B) of red leaf lettuce leaves. Vertical bars represent the means \pm SEs $(n=4)$. Different letters indicate significant differences as determined by the Tukey's multiple comparison test $(p<0.05)$. 


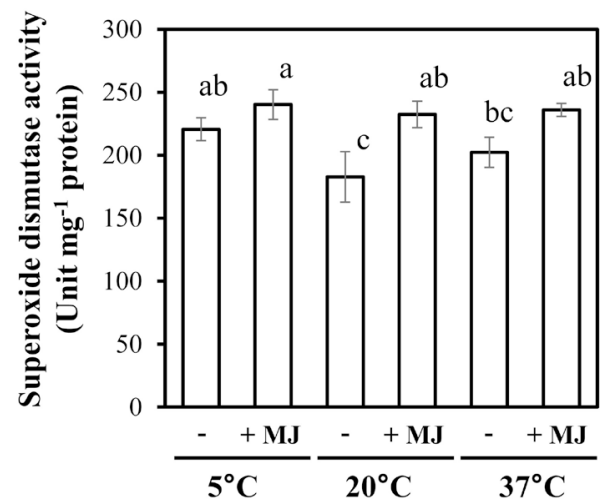

Figure 7. Effects of night temperature and MJ on the activity of SOD in red leaf lettuce leaves. Vertical bars represent the means \pm SEs $(n=4)$. Different letters indicate significant differences as determined by the Tukey's multiple comparison test $(p<0.05)$.

sults show that the exposure of red leaf lettuce plants to a low night temperature triggers anthocyanin accumulation in their leaves. When stressed by low temperatures, plants can activate the expression of a variety of genes, some of which are involved in the biosynthesis of anthocyanin, such as $P A L, C H S$, and $C H I$ in many plant species [32] [33] [34] [35] [36]. In lettuce, these anthocyanin biosynthesis genes can be transcriptionally regulated by the Arabidopsis MYB transcription factor AtMYB60 [37]. Given that MYB transcriptional factors are common regulators of the anthocyanin synthesis pathway in many plant species [38], the modulation of the temperature-responsive transcriptional factors that orchestrate the expression of the involved anthocyanin biosynthesis genes may offer a strategy for increasing the content of this valuable metabolite in lettuce crops. In this study, the plants underwent the temperature stresses during the night period only, which did not significantly affect their leaf biomass. This suggests that the method of a periodical temperature stress treatment may allow for the efficient production of valuable metabolites.

\subsection{Effect of High Night Temperature on the Production of Anthocyanin}

High temperature also modulates the production of anthocyanin, a process that is well studied, especially in fruit vegetables [9] [39] [40]. In apples and grapes, the colors of their fruits decrease under high temperatures due to the downregulation of anthocyanin accumulation [39] [40]. In accord with this, increasing the growing temperature decreases the expression of several genes encoding the transcription factors that regulate the anthocyanin synthetic genes [39] [41]. In prior studies, anthocyanin production in lettuce decreased when the growing temperatures were increased [18] [20] [42]. In contrast to that finding, here we found that a high night temperature enhances the anthocyanin content in red leaf lettuce leaves. Because the high temperature treatment in those previous studies was set $25^{\circ} \mathrm{C}-30^{\circ} \mathrm{C}$ lower than that used in our present study $\left(37^{\circ} \mathrm{C}\right)$, those temperatures might be insufficient to activate the heat stress signaling associated with the anthocyanin synthesis. It is also possible that the modest high 
temperature stimuli used in previous studies may have caused alternations of the growth and metabolites as a result of a plant acclimation response to the modest temperature shift. Indeed, when 1-month-old sugarcane sprouts were exposed to more severe condition of heat stress $\left(40^{\circ} \mathrm{C}\right)$, within $24 \mathrm{~h}$ this treatment had triggered anthocyanin accumulation in them [43]. Given that exposure to $35^{\circ} \mathrm{C}$ increased the phenolic compounds in tomato though this same treatment did not do so in watermelon plants [44], the particular temperature required for the induction of heat stress responses is likely species- and cultivar-dependent.

\subsection{Synergistic Effects of Night Temperature and MJ on the Production of Anthocyanin and the Oxidative Stress Response}

Previously, we demonstrated that $\mathrm{MJ}$ induced the anthocyanin production in red leaf lettuce in a light-dependent manner [21]. Here, we show that MJ accelerated the accumulation of anthocyanin in leaves triggered by the treatment with low or high night temperatures. Jasmonic acid (JA) is produced in response to biotic and abiotic stresses, and it acts as a signal molecule in the synthesis of flavonoids, such as anthocyanin [10] [45]. Alone, both JA and MJ can induce anthocyanin production in Arabidopsis by activating the expression of the anthocyanin biosynthesis genes $P A L, C H S, D F R, L D O X$, and UF3GT [15]. In guava fruits, an MJ treatment in combination with a $5^{\circ} \mathrm{C}$-low temperature treatment increased PAL activity, which in turn led to the accumulation of total phenols [46]. Given that a low temperature stress is known to activate the anthocyanin biosynthetic genes in several plants [32] [33] [34] [35] [36], and that the low temperatureinduced expressions of these genes were dependent on light [47], the augmentation of a low night temperature-induced anthocyanin accumulation by $\mathrm{MJ}$ in the red leaf lettuce plants may be caused by the cumulative upregulation of gene expression related to anthocyanin synthesis.

Chilling and heat stresses can trigger oxidative stress responses, including the production of reactive oxygen species which could play a key role in mediating important signal transduction responses involved in plant tolerance to changing temperatures [48]. Similar to this, in the present study, either a high or low night temperature treatment was able to induce $\mathrm{H}_{2} \mathrm{O}_{2}$ production and lipid peroxidation in the red leaf lettuce plants. These oxidative stress parameters were also upregulated by the MJ treatment regardless of the night temperature condition, and they were closely related to the production of anthocyanin. Anthocyanins are involved in several stress responses, namely as antioxidants that alleviate the oxidative damage in plants [49] [50] [51] [52] [53]. Considering that JA is also a mediator of oxidative stress responses and is involved in plant adaptation to mitigate several stresses [54], the increased production of anthocyanin in our experiments is among the antioxidative responses that resulted from the heat, chilling, and JA-mediated stress responses. The augmentation effects of $\mathrm{MJ}$ on anthocyanin synthesis, $\mathrm{H}_{2} \mathrm{O}_{2}$ accumulation, and lipid peroxidation, were more evident in those lettuce plants exposed to high night temperature as compared with those exposed to the low or control $\left(20^{\circ} \mathrm{C}\right)$ night temperatures. Interestingly, in 
rice plants, the endogenous JA content is markedly increased under cold stress but it is reduced by heat stress [55]. In soybean plants, ethylene synthesis is activated under high temperature stress, which triggers premature leaf senescence by increasing the superoxide radical and $\mathrm{H}_{2} \mathrm{O}_{2}$ content, as well as membrane damage [56] [57]. Given that the color pigmentation of apple skin is enhanced by both MJ and ethylene, and enhanced by their combined treatment [58], the augmentation effect of the oxidative responses triggered by the high night temperature in combination with the MJ treatment may be driven by the dual induction of ethylene-dependent and JA-dependent signaling for anthocyanin synthesis.

In the present study, the low night temperature and the MJ treatment significantly decreased the leaf water content in red leaf lettuce, thus indicating a modest drought stress to leaves. Anthocyanin is produced in response to drought stress and it is involved in tolerance to this stress [17] [59] [60]. In Arabidopsis, the oxidative and drought tolerances are enhanced by an overaccumulation of antioxidant flavonoids, including anthocyanins [59]. Given that anthocyanin production is negatively related with the leaf water content in the present study, the low night temperature and $\mathrm{MJ}$ treatments may induce anthocyanin production in red leaf lettuce in part via the activation of drought stress signaling. Thus, the regulation of plant water status by manipulating the hydroponic cultivation system might be a useful way to further modulate the productionof anthocyanin in crops of red leaf lettuce.

\subsection{Conclusion}

Our experimental results indicate that the combined treatment of multiple stimuli, such as the night temperature shift and the MJ treatment, could be a useful strategy to modulate plant secondary metabolite production in red leaf lettuce. Even if a single stress treatment is effective at increasing the content of valuable plant metabolites, this effect seems to be less than that arising from multiple stimuli treatments. Given that a single stimulus is required for a relatively longterm period to accumulate anthocyanin in plants, this may eventually affect the plant biomass of lettuce. Therefore, providing multiple short-term stimuli just before harvesting potentially offers a simple and effective way for many plants of a crop to gain more valuable metabolites while minimizing the stimuli's influence on plant biomass.

\section{References}

[1] Akula, R. and Ravishankar, G.A. (2011) Influence of Abiotic Stress Signals on Secondary Metabolites in Plants. Plant Signaling \& Behavior, 6, 1720-1731. https://doi.org/10.4161/psb.6.11.17613

[2] Zhao, J., Davis, L.C. and Verpoorte, R. (2005) Elicitor Signal Transduction Leading to Production of Plant Secondary Metabolites. Biotechnology Advances, 23, 283333.

[3] Kaplan, F., Kopka, J., Haskell, D.W., Zhao, W., Schiller, K.C., Gatzke, N., Sung, D.Y. and Guy, C.L. (2004) Exploring the Temperature-Stress Metabolome of Arabidop- 
sis. Plant Physiology, 136, 4159-4168. https://doi.org/10.1104/pp.104.052142

[4] Zobayed, S.M.A., Afreen, F. and Kozai, T. (2005) Temperature Stress Can Alter the Photosynthetic Efficiency and Secondary Metabolite Concentrations in St. John's wort. Plant Physiology and Biochemistry, 43, 977-984.

[5] Ramakrishna, A. and Ravishankar, G.A. (2011) Influence of Abiotic Stress Signals on Secondary Metabolites in Plants. Plant Signaling \& Behavior, 6, 1720-1731. https://doi.org/10.4161/psb.6.11.17613

[6] Jochum, G.M., Mudge, K.W. and Thomas, R.B. (2007) Elevated Temperatures Increase Leaf Senescence and Root Secondary Metabolite Concentrations in the Understory Herb Panax quinquefolius (Araliaceae). American Journal of Botany, 94, 819-826. https://doi.org/10.3732/ajb.94.5.819

[7] Tamura, A. (2004) Effect of Air Temperature on the Content of Sugar and Vitamin C of Spinach and Komatsuna. HorticulturalResearch (Japan), 3, 187-190. https://doi.org/10.2503/hrj.3.187

[8] Wang, S.Y. and Camp, M.J. (2000) Temperatures after Bloom Affect Plant Growth and Fruit Quality of Strawberry. Scientia Horticulturae, 85, 183-199.

[9] Ikeda, T., Yamazaki, K., Kumakura, H. and Hamamoto, H. (2011) The Effects of High Temperature and Water Stresson Fruit Growth and Anthocyanin Content of Pot-Grown Strawberry (Fragaria $\times$ ananassa Duch. cv. "Sachinoka") Plants. Environment Control in Biology, 49, 209-215. https://doi.org/10.2525/ecb.49.209

[10] Creelman, R.A. and Mullet, J.E. (1995) Jasmonic Acid Distribution and Action in Plants: Regulation during Development and Response to Biotic and Abiotic Stress. Proceedings of the National Academy of Sciences, 92, 4114-4119. https://doi.org/10.1073/pnas.92.10.4114

[11] Cheong, J.J. and Do Choi, Y. (2003) Methyl Jasmonate as a Vital Substance in Plants. Trends in Genetics, 19, 409-413.

[12] Kim, H.J., Chen, F., Wang, X. and Rajapakse, N.C. (2006) Effect of Methyl Jasmonate on Secondary Metabolites of Sweet Basil (Ocimum basilicum L.). Journal of Agricultural and Food Chemistry, 54, 2327-2332. https://doi.org/10.1021/jf051979g

[13] Keinänen, M., Oldham, N.J. and Baldwin, I.T. (2001) Rapid HPLC Screening of Jasmonate-Induced Increases in Tobacco Alkaloids, Phenolics, and Diterpene Glycosides in Nicotiana attenuata. Journal of Agricultural and Food Chemistry, 49, 3553-3558. https://doi.org/10.1021/jf010200+

[14] Wang, S.Y. and Zheng, W. (2005) Preharvest Application of Methyl Jasmonate Increases Fruit Quality and Antioxidant Capacity in Raspberries. International Journal of Food Science \& Technology, 40, 187-195. https://doi.org/10.1111/j.1365-2621.2004.00930.x

[15] Shan, X., Zhang, Y., Peng, W., Wang, Z. and Xie, D. (2009) Molecular Mechanism for Jasmonate-Induction of Anthocyanin Accumulation in Arabidopsis. Journal of Experimental Botany, 60, 3849-3860. https://doi.org/10.1093/jxb/erp223

[16] Stintzing, F.C. and Carle, R. (2004) Functional Properties of Anthocyanins and Betalains in Plants, Food, and in Human Nutrition. Trends in Food Science \& Technology, 15, 19-38.

[17] Chalker-Scott, L. (1999) Environmental Significance of Anthocyanins in Plant Stress Responses. Photochemistry and Photobiology, 70, 1-9.

https://doi.org/10.1111/j.1751-1097.1999.tb01944.x

[18] Gazula, A., Kleinhenz, M.D., Streeter, J.G. and Miller, A.R. (2005) Temperature and Cultivar Effects on Anthocyanin and Chlorophyll b Concentrations in Three Related Lollo Rosso Lettuce Cultivars. HortScience, 40, 1731-1733. 
[19] Boo, H.O., Heo, B.G., Gorinstein, S. and Chon, S.U. (2011) Positive Effects of Temperature and Growth Conditions on Enzymatic and Antioxidant Status in Lettuce Plants. Plant Science, 181, 479-484.

[20] Kleinhenz, M.D., Gazula, A., Scheerens, J.C. and French, D.G. (2003) Variety, Shading, and Growth Stage Effects on Pigment Concentrations in Lettuce Grown under Contrasting Temperature Regimens. HortTechnology, 13, 677-683.

[21] Sakamoto, M. and Suzuki, T. (2015) Effects of Plant Defense Elicitors on Anthocyanin Accumulation in Red Baby Leaf Lettuce. Memoirs of the Faculty of Biology-Oriented Science and Technology of Kinki University, 35, 1-6.

[22] Kim, H.J., Fonseca, J.M., Choi, J.H. and Kubota, C. (2007) Effect of Methyl Jasmonate on Phenolic Compounds and Carotenoids of Romaine Lettuce (Lactuca sativa L.). Journal of Agricultural and Food Chemistry, 55, 10366-10372. https://doi.org/10.1021/jf071927m

[23] Curtin, C., Zhang, W. and Franco, C. (2003) Manipulating Anthocyanin Composition in Vitis vinifera Suspension Cultures by Elicitation with Jasmonic Acid and Light Irradiation. Biotechnology Letters, 25, 1131-1135.

https://doi.org/10.1023/A:1024556825544

[24] Park, W.T., Kim, Y.B., Seo, J.M., Kim, S.J., Chung, E., Lee, J.H. and Park, S.U. (2013) Accumulation of Anthocyanin and Associated Gene Expression in Radish Sprouts Exposed to Light and Methyl Jasmonate. Journal of Agricultural and Food Chemistry, 61, 4127-4132. https://doi.org/10.1021/jf400164g

[25] Sakamoto, M. and Suzuki, T. (2015) Effect of Root-Zone Temperature on Growth and Quality of Hydroponically Grown Red Leaf Lettuce (Lactuca sativa L. cv. Red Wave). American Journal of Plant Sciences, 6, 2350-2360. https://doi.org/10.4236/ajps.2015.614238

[26] Weisany, W., Sohrabi, Y., Heidari, G., Siosemardeh, A. and Ghassemi-Golezani, K. (2012) Changes in Antioxidant Enzymes Activity and Plant Performance by Salinity Stress and Zinc Application in Soybean (Glycine max L.). Plant Omics, 5, 60-67.

[27] Sakamoto, M., Tada, Y., Nakayashiki, H., Tosa, Y. and Mayama, S. (2005) Two Phases of Intracellular Reactive Oxygen Species Production during Victorin-Induced Cell Death in Oats. Journal of General Plant Pathology, 71, 387-394. https://doi.org/10.1007/s10327-005-0220-5

[28] Salbitani, G., Vona, V., Bottone, C., Petriccione, M. and Carfagna, S. (2015) Sulfur Deprivation Results in Oxidative Perturbation in Chlorella sorokiniana (211/8k). Plant and Cell Physiology, 56, 897-905. https://doi.org/10.1093/pcp/pcv015

[29] Vanderauwera, S., Zimmermann, P., Rombauts, S., Vandenabeele, S., Langebartels, C., Gruissem, W., Inze, D. and Van Breusegem, F. (2005) Genome-Wide Analysis of Hydrogen Peroxide-Regulated Gene Expression in Arabidopsis Reveals a High Light-Induced Transcriptional Cluster Involved in Anthocyanin Biosynthesis. Plant Physiology, 139, 806-821. https://doi.org/10.1104/pp.105.065896

[30] Fahnenstich, H., Scarpeci, T.E., Valle, E.M., Flügge, U.I. and Maurino, V.G. (2008) Generation of Hydrogen Peroxide in Chloroplasts of Arabidopsis Overexpressing Glycolate Oxidase as an Inducible System to Study Oxidative Stress. Plant Physiology, 148, 719-729. https://doi.org/10.1104/pp.108.126789

[31] Alscher, R.G., Erturk, N. and Heath, L.S. (2002) Role of Superoxide Dismutases (SODs) in Controlling Oxidative Stress in Plants. Journal of Experimental Botany, 53, 1331-1341. https://doi.org/10.1093/jxb/53.372.1331

[32] Christie, P.J., Alfenito, M.R. and Walbot, V. (1994) Impact of Low-Temperature Stress on General Phenylpropanoid and Anthocyanin Pathways: Enhancement of Transcript Abundance and Anthocyanin Pigmentation in Maize Seedlings. Planta, 
194, 541-549. https://doi.org/10.1007/BF00714468

[33] Shvarts, M., Borochov, A. and Weiss, D. (1997) Low Temperature Enhances Petunia Flower Pigmentation and Induces Chalcone Synthase Gene Expression. Physiologia Plantarum, 99, 67-72. https://doi.org/10.1111/j.1399-3054.1997.tb03432.x

[34] Hasegawa, H., Fukasawa-Akada, T., Okuno, T., Niizeki, M. and Suzuki, M. (2001) Anthocyanin Accumulation and Related Gene Expression in Japanese Parsley (Oenanthe stolonifera, DC.) Induced by Low Temperature. Journal of Plant Physiology, 158, 71-78. https://doi.org/10.1078/0176-1617-00038

[35] Wang, L., Li, X., Zhao, Q., Jing, S., Chen, S. and Yuan, H. (2009) Identification of Genes Induced in Response to Low-Temperature Treatment in Tea Leaves. Plant Molecular Biology Reporter, 27, 257-265.

https://doi.org/10.1007/s11105-008-0079-7

[36] Catalá, R., Medina, J. and Salinas, J. (2011) Integration of Low Temperature and Light Signaling during Cold Acclimation Response in Arabidopsis. Proceedings of the National Academy of Sciences, 108, 16475-16480. https://doi.org/10.1073/pnas.1107161108

[37] Park, J.S., Kim, J.B., Cho, K.J., Cheon, C.I., Sung, M.K., Choung, M.G. and Roh, K.H. (2008) Arabidopsis R2R3-MYB Transcription Factor AtMYB60 Functions as a Transcriptional Repressor of Anthocyanin Biosynthesis in Lettuce (Lactuca sativa). Plant Cell Reports, 27, 985-994. https://doi.org/10.1007/s00299-008-0521-1

[38] Petroni, K. and Tonelli, C. (2011) Recent Advances on the Regulation of Anthocyanin Synthesis in Reproductive Organs. Plant Science, 181, 219-229.

[39] Mori, K., Goto-Yamamoto, N., Kitayama, M. and Hashizume, K. (2007) Loss of Anthocyanins in Red-Wine Grape under High Temperature. Journal of Experimental Botany, 58, 1935-1945. https://doi.org/10.1093/jxb/erm055

[40] Lin-Wang, K.U.I., Micheletti, D., Palmer, J., Volz, R., Lozano, L., Espley, R., Hellens, R.P., Chagne, D., Rowan, D.D., Troggio, M., Iglesias, I. and Allan, A.C. (2011) High Temperature Reduces Apple Fruit Colour via Modulation of the Anthocyanin Regulatory Complex. Plant, Cell \& Environment, 34, 1176-1190.

https://doi.org/10.1111/j.1365-3040.2011.02316.x

[41] Rowan D.D., Cao M., Lin-Wang K., Cooney, J.M., Jensen, D.J., Austin, P.T., Hunt, M.B., Norling, C., Hellens, R.P., Schaffer, R.J. and Allan, A.C. (2009) Environmental Regulation of Leaf Colour in Red 35S:PAP1 Arabidopsis thaliana. New Phytologist, 182, 102-115. https://doi.org/10.1111/j.1469-8137.2008.02737.x

[42] Dalla Costa, L., Tomasi, N. and Gottardi, S. (2011) The Effect of Growth Medium Temperature on Corn Salad [Valerianella locusta (L.) Laterr] Baby Leaf Yield and Quality. HortScience, 46, 1619-1625.

[43] Wahid, A. (2007) Physiological Implications of Metabolite Biosynthesis for Net Assimilation and Heat-Stress Tolerance of Sugarcane (Saccharum officinarum) Sprouts. Journal of plant Research, 120, 219-228. https://doi.org/10.1007/s10265-006-0040-5

[44] Rivero, R.M., Ruiz, J.M., Garcıa, P.C., Lopez-Lefebre, L.R., Sánchez, E. and Romero, L. (2001) Resistance to Cold and Heat Stress: Accumulation of Phenolic Compounds in Tomato and Watermelon Plants. Plant Science, 160, 315-321.

[45] Gundlach, H., Müller, M.J., Kutchan, T.M. and Zenk, M.H. (1992) Jasmonic Acid Is a Signal Transducer in Elicitor-Induced Plant Cell Cultures. Proceedings of the National Academy of Sciences, 89, 2389-2393. https://doi.org/10.1073/pnas.89.6.2389

[46] González-Aguilar, G.A., Tiznado-Hernandez, M.E., Zavaleta-Gatica, R. and Martınez-Téllez, M.A. (2004) Methyl Jasmonate Treatments Reduce Chilling Injury 
and Activate the Defense Response of Guava Fruits. Biochemical and Biophysical Research Communications, 313, 694-701.

[47] Leyva, A., Jarillo, J.A., Salinas, J. and Martinez-Zapater, J.M. (1995) Low Temperature Induces the Accumulation of Phenylalanine Ammonia-Lyase and Chalcone Synthase mRNAs of Arabidopsis thaliana in a Light-Dependent Manner. Plant Physiology, 108, 39-46. https://doi.org/10.1104/pp.108.1.39

[48] Suzuki, N. and Mittler, R. (2006) Reactive Oxygen Species and Temperature Stresses: A Delicate Balance between Signaling and Destruction. Physiologia Plantarum, 126, 45-51. https://doi.org/10.1111/j.0031-9317.2005.00582.x

[49] Gould, K.S., McKelvie, J. and Markham, K.R. (2002) Do Anthocyanins Function as Antioxidants in Leaves? Imaging of $\mathrm{H}_{2} \mathrm{O}_{2}$ in Red and Green Leaves after Mechanical Injury. Plant, Cell \& Environment, 25, 1261-1269. https://doi.org/10.1046/j.1365-3040.2002.00905.x

[50] Neill, S.O. and Gould, K.S. (2003) Anthocyanins in Leaves: Light Attenuators or Antioxidants? Functional Plant Biology, 30, 865-873.

https://doi.org/10.1071/FP03118

[51] Shao, L., Shu, Z., Sun, S.L., Peng, C.L., Wang, X.J. and Lin, Z.F. (2007) Antioxidation of Anthocyanins in Photosynthesis under High Temperature Stress. Journal of Integrative Plant Biology, 49, 1341-1351. https://doi.org/10.1111/j.1744-7909.2007.00527.x

[52] Zhang, Q., Su, L.J., Chen, J.W., Zeng, X.Q., Sun, B.Y. and Peng, C.L. (2012) The Antioxidative Role of Anthocyanins in Arabidopsis under High-Irradiance. Biologia Plantarum, 56, 97-104. https://doi.org/10.1007/s10535-012-0022-5

[53] Havaux, M. and Kloppstech, K. (2001) The Protective Functions of Carotenoid and Flavonoid Pigments against Excess Visible Radiation at Chilling Temperature Investigated in Arabidopsisnpq and $t t$ Mutants. Planta, 213, 953-966. https://doi.org/10.1007/s004250100572

[54] Sasaki-Sekimoto, Y., Taki, N., Obayashi, T., Aono, M., Matsumoto, F., Sakurai, N., Suzuki, H., Yokota-Hirai, M., Noji, M., Saito, K., Matsuda, T., Takamiya, K., Shibata, D. and Ohta, H. (2005) Coordinated Activation of Metabolic Pathways for Antioxidants and Defence Compounds by Jasmonates and Their Roles in Stress Tolerance in Arabidopsis. The Plant Journal, 44, 653-668. https://doi.org/10.1111/j.1365-313X.2005.02560.x

[55] Du, H., Liu, H. and Xiong, L. (2013) Endogenous Auxin and Jasmonic Acid Levels Are Differentially Modulated by Abiotic Stresses in Rice. Frontiers in Plant Science, 4, 397. https://doi.org/10.3389/fpls.2013.00397

[56] Djanaguiraman, M. and Prasad, P.V. (2010) Ethylene Production under High Temperature Stress Causes Premature Leaf Senescence in Soybean. Functional Plant Biology, 37, 1071-1084. https://doi.org/10.1071/FP10089

[57] Bita, C. and Gerats, T. (2013) Plant Tolerance to High Temperature in a Changing Environment: Scientific Fundamentals and Production of Heat Stress-Tolerant Crops. Frontiers in Plant Science, 4, 273. https://doi.org/10.3389/fpls.2013.00273

[58] Rudell, D.R. and Mattheis, J.P. (2008) Synergism Exists between Ethylene and Methyl Jasmonate in Artificial Light-Induced Pigment Enhancement of "Fuji" Apple Fruit Peel. Postharvest Biology and Technology, 47, 136-140.

[59] Nakabayashi, R., Yonekura-Sakakibara, K., Urano, K., Suzuki, M., Yamada, Y., Nishizawa, T., Matsuda, F., Kojima, M., Sakakibara, H., Shinozaki, K., Michael, A.J., Tohge, T., Yamazaki, M. and Saito, K. (2014) Enhancement of Oxidative and Drought Tolerance in Arabidopsis by Overaccumulation of Antioxidant Flavonoids. The Plant Journal, 77, 367-379. https://doi.org/10.1111/tpj.12388 
[60] Sperdouli, I. and Moustakas, M. (2012) Interaction of Proline, Sugars, and Anthocyanins during Photosynthetic Acclimation of Arabidopsis thaliana to Drought Stress. Journal of Plant Physiology, 169, 577-585.

Submit or recommend next manuscript to SCIRP and we will provide best service for you:

Accepting pre-submission inquiries through Email, Facebook, LinkedIn, Twitter, etc. A wide selection of journals (inclusive of 9 subjects, more than 200 journals)

Providing 24-hour high-quality service

User-friendly online submission system

Fair and swift peer-review system

Efficient typesetting and proofreading procedure

Display of the result of downloads and visits, as well as the number of cited articles Maximum dissemination of your research work

Submit your manuscript at: http://papersubmission.scirp.org/

Or contact ajps@scirp.org 